Research Report No. 11/2012

\title{
Privatizing the Economic Constitution- Can the World Market Reproduce its Own Institutional Prerequisites?
}

Gralf-Peter Calliess

Jens Mertens

Moritz Renner

Follow this and additional works at: http:/ / digitalcommons.osgoode.yorku.ca/clpe

\section{Recommended Citation}

Calliess, Gralf-Peter; Mertens, Jens; and Renner, Moritz, "Privatizing the Economic Constitution- Can the World Market Reproduce its Own Institutional Prerequisites?" (2012). Comparative Research in Law \& Political Economy. Research Paper No. 11/2012.

http://digitalcommons.osgoode.yorku.ca/clpe/10 


\section{OSGOODE}

\section{OSGOODE HALL LAW SCHOOL}

Comparative Research in Law \& Political Economy

RESEARCH PAPER SERIES

Research Paper No. 11/2012

\section{Privatizing the Economic Constitution- Can the World Market Reproduce its own Institutional Prerequisites?}

Gralf-Peter Calliess, Jens Mertens, Mortiz Renner

Editors:

Peer Zumbansen (Osgoode Hall Law School, Toronto, Director, Comparative Research in Law and Political Economy)

John W. Cioffi (University of California at Riverside)

Leeanne Footman (Osgoode Hall Law School, Toronto, Production Editor)

Comparative Research in Law \& Political Economy

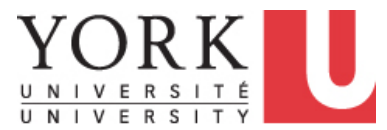


Osgoode CLPE Research Paper 11/2012

Vol. 08 No. 03 (2012)

Gralf-Peter Calliess, Jens Mertens, Moritz Renner'

\title{
Privatizing the Economic Constitution- Can the World Market Reproduce its own Institutional Prerequisites?
}

\begin{abstract}
Markets are not a natural phenomenon but depend on a complex set of institutions. Commercial law enables and facilitates at-arm's-length market exchange. Competition law regulates freedom of contract in order to protect it from self-abolition. On the domestic level, these core pillars of the economic constitution have been safely installed by the modern nation state. However, on the global level the situation is different. Since in contrast to domestic trade, cross-border transactions are not conducted "in the shadow of law" but largely depend on private governance-mechanisms, the crucial question is whether the world market is able to reproduce its own institutional prerequisites. Consequently, we assess the potential effects of this privatization of commercial law on competition policy, namely the potential abuse of market-dominating positions resulting from a rise in the level of vertical integration on the world market as well as the potential of contracting around the ban on cartels by choosing arbitration rather than litigation as a means of commercial dispute resolution.
\end{abstract}

Key words: private law, contract enforcement, economic constitution, cross-border contracts, competition policy, vertical integration, international arbitration, private ordering, antitrust

\footnotetext{
$1{ }^{*}$ This article is based on the authors' joint research conducted within the framework of the Collaborative Research Center 597 "Transformations of the State" in Bremen (http://www.staat.uni-bremen.de/?SPRACHE=en). It especially builds on work published in the following articles: Calliess/Mertens, Transnational Corporations, global Competition Policy, and the Shortcomings of Private International Law, Ind. J. Global Legal Stud. 18 (2011) p. 843 872; Calliess/Renner, The Public and the Private Dimensions of Transnational Commercial Law, German L. J. 10 (2009) 10, p. 1341-1356; Renner, Towards a Hierarchy of Norms in Transnational Law?, J. Int'l Arb. 26 (2009) 4, p. 533-555
} 


\section{Privatizing the Economic Constitution - Can the World Market Reproduce its own Institutional Prerequisites? Gralf-Peter Calliess, Jens Mertens, Moritz Renner*}

"Commerce ... can seldom flourish long in any state ..., in which the faith of contracts is not supported by law ..." Adam Smith $^{2}$

"The inability of societies to develop effective, low-cost enforcement of contracts is the most important source of both historical stagnation and contemporary underdevelopment ..."

Douglass C. North ${ }^{3}$

\section{INTRODUCTION}

Markets are a result of social organization rather than a natural phenomenon. Commerce, defined as the marketing of goods and services, is dependent on a complex set of institutions among which commercial and competition law figure quite prominently. Commercial law, understood as a set of efficacious institutions for the enforcement of contracts, enables and facilitates atarm's-length market exchange. Competition law, consisting of a ban on cartels, a prohibition of the abuse of dominant positions, and merger control, regulates freedom of contract in order to protect it from self-abolition. Taken together, commercial and competition law make up the core pillar of what was called the 'economic constitution' of market economies by German ordoliberalism. ${ }^{4}$ Historically, the evolution of the economic constitution was tied to the nation state, and in case of the European internal market to the EU supranational legal system as backed by the Member States. After globalization, which entity provides the economic constitution of the world market? The WTO might be a candidate, but for now does not qualify as a provider of commercial and competition law. In the absence of a world state as a regulator, can the world market produce its own economic constitution by means of private ordering?

Indeed, many scholars claim that the global economy has generated private legal regimes for the enforcement of contracts, e.g. the New Law Merchant as a transnational commercial law. ${ }^{5}$

\footnotetext{
* This article is based on the authors' joint research conducted within the framework of the Collaborative Research Center 597 "Transformations of the State" in Bremen (http://www.staat.uni-bremen.de/?SPRACHE=en). It especially builds on work published in the following articles: Calliess/Mertens, Transnational Corporations, global Competition Policy, and the Shortcomings of Private International Law, Ind. J. Global Legal Stud. 18 (2011) p. 843872; Calliess/Renner, The Public and the Private Dimensions of Transnational Commercial Law, German L. J. 10 (2009) 10, p. 1341-1356; Renner, Towards a Hierarchy of Norms in Transnational Law?, J. Int'l Arb. 26 (2009) 4, p. 533-555.

${ }^{2}$ An Inquiry into the Nature and Causes of the Wealth of Nations II, 1778, p. $539 \mathrm{f}$.

${ }^{3}$ Institutions, Institutional Change and Economic Performance, 1990, p. 54

${ }^{4}$ Böhm, Wettbewerb und Monopolkampf. Eine Untersuchung zur Frage des wirtschaftlichen Kampfrechts und zur Frage der rechtlichen Struktur der geltenden Wirtschaftsordnung, 1933; Behrens, Weltwirtschaftsverfassung, Jahrbuch für Neue Politische Ökonomie 19 (2000) p. 5-27.

5 Teubner, 'Global Bukowina': Legal Pluralism in the World Society, in: Teubner (ed), Global Law without a State, 1997, p. 3; Berger, The creeping codification of the lex mercatoria, 1999; Stone Sweet, The New Lex Mercatoria and Transnational Governance, Journal of European Public Policy 13 (2006) p. 627-646; Calliess, Transnational Civil Regimes: Economic Globalisation and the Evolution of Commercial Law, in: Gessner (ed), Contractual Certainty in International Trade - Empirical Studies and Theoretical Debates on Institutional Support for Global Economic Exchanges, 2009, p. 215-238; Calliess et al., Transformations of Commercial Law: New Forms of Legal Certainty for Globalized Exchange Processes?, in: Hurrelmann et al. (ed), Transforming the Golden Age Nation State, 2007, p. 83-108.
} 
Moreover, Gunther Teubner suggests that such private regimes are subject to auto-constitutional processes which enable them to reflect public policy considerations. ${ }^{6}$ In the context of the economic constitution, this would imply that private actors on "the law market ${ }^{7}$ do not only provide efficacious contract enforcement institutions, but also that they are able to prevent contracting parties from distorting competition through cartel agreements, for example. So are 'merchants of law' also acting as 'moral entrepreneurs ${ }^{8}$ when it comes to competition policy as a public good?

In this article we intend to analyze in some detail the potential anti-competitive effects of a privatization of commercial law and we discuss to what extent the self-constitutionalization of private regimes may be understood as a privatization of competition law. In a first step, we will argue that the institutional organization of cross-border commerce differs in fundamental ways from what we know from domestic markets due to the lower level of legal certainty created by the state legal system. Secondly, we will illustrate how international traders adapt to these differences by employing private governance mechanisms such as vertical integration (uniform governance) or international commercial arbitration (trilateral governance) in order to support their trade. Thirdly, we will assess the potential effects of this privatization of commercial law on competition policy, namely the potential abuse of market-dominating positions resulting from a rise in the level of vertical integration on the world market as well as the potential of contracting around the ban on cartels by choosing arbitration rather than litigation as a means of commercial dispute resolution.

\section{QUALITY OF COMMERCIAL LAW AS CRUCIAL FACTOR FOR THE INSTITUTIONAL ORGANIZATION OF COMMERCE}

Institutions are the foundation of economic exchange. Prominently defined by Douglass C. North as "the rules of the game in a society or, more formally, $[\ldots]$ the humanly devised constraints that shape human interaction", institutions allow economic actors to predict the behaviour of potential trade partners, turning uncertainty into calculable risk and thus allowing transactions to take place. What kind of institutions a society will develop, however, is largely dependent on external factors. In the following sections we will show that due to the deficiencies of private law on the international level, the 'society of traders' engaged in cross-border commerce has developed institutions different from those employed in domestic trade, calling for differentiated considerations as far as competition in international market structures is concerned.

\footnotetext{
${ }^{6}$ Teubner, Global Private Regimes: Neo-spontaneous Law and Dual Constitution of Autonomous Sectors in World Society, in: Teubner/Ladeur (ed), Globalization and Public Governance, 2004, p. 71 ; Teubner, Constitutional Fragments. Societal Constitutionalism and Globalization, 2012.

${ }^{7}$ O'Hara/Ribstein, The law market, 2009.

${ }^{8}$ Dezalay/Garth, Merchants of Law as Moral Entrepreneurs: Constructing International Justice from the Competition for Transnational Business Disputes, Law \& Society Review 29 (1995) 1, p. 27.

${ }^{9}$ North, Institutions, Institutional Change and Economic Performance, 1990, at p. 3. For more specific information on the role of institutions in cross-border trade cf. to Dietz, Institutionen und Globalisierung - Eine empirische Untersuchung am Beispiel grenzüberschreitender Softwareentwicklungsverträge, 2010.
} 
Deficient contract-enforcement and protection of property rights in international trade

Transactions are always threatened by uncertainty, resulting from the opportunistic behaviour of human beings. Only if payment and delivery happen simultaneously, no further institutional embedding of a transaction seems necessary. However, in a modern society based on the division of labour and credit, it is inevitable that goods and services are exchanged across large distances and time spans. With no direct means of control left, any party making an advance delivery or payment risks losing its transaction input, since for the other party it is the economically most reasonable behaviour to refrain from making delivery or payment and thus to double profits. Because of this risk, no party will move in advance. Consequently, the transaction will not take place at all.

In order to overcome this so-called 'prisoner's dilemma', a party which moves in advance must be able to expect with sufficient certainty that its counterpart will fulfil its contractual obligations. Within the modern nation state, this protection is granted by a judicial system that creates legal certainty with regard to the enforcement of contracts. Acting "in the shadow of law", ${ }^{10}$ traders have a strong incentive to fulfil their contractual obligations since the costs of losing a lawsuit exceed the gain from cheating. ${ }^{11}$ The enforcement of contracts and the protection of property rights - in short commercial law - thus form part of the economic constitution allowing economic exchange between anonymous parties. Commercial law, therefore, is a prerequisite for the emergence of competitive market structures.

However, in the absence of a 'world state', there is no supranational world private law regime that would generate a similar level of contractual certainty for cross-border trade. The judicial settling of conflicts concerning cross-border transactions, therefore, poses always three questions: (1) Which nation's courts are responsible for resolving the conflict? (2) Which national contract law are these courts supposed to apply in resolving the conflict? (3) Is a judgment from one nation state recognized and enforced in another nation state? ${ }^{12}$

In theory, these issues are addressed by private international law (PIL). Contrary to the wording, however, PIL does not represent international uniform law. Rather, each state's legal system has its own conflict of laws provisions. Although the idea of a global private law based on contracts under international law emerged already at the end of the 19 th century, ${ }^{13}$ more than a century of work in different international organizations, such as the Hague Conference on Private International Law (since 1893), the International Institute for the Unification of Private Law (UNIDROIT, since 1926) and the United Nations Commission on International Trade Law (UNCITRAL, since 1966), have only produced piecemeal results, like the UN Convention on the International Sale of Goods (CISG) of $1980 .{ }^{14}$ Hence, the transacting parties are confronted with a plethora of different conflict of laws rules and substantive norms. They cannot rely on enforcement by state courts, as there is still no global agreement on the recognition and

\footnotetext{
${ }^{10}$ Cf. to Dixit, Lawlessness and Economics: Alternative Modes of Governance, 2004, at p. 10.

${ }^{11}$ For an in-depth analysis of the function of a state-organized private law system cf. to Mertens, Privatrechtsschutz und vertikale Integration im internationalen Handel, 2011, at p. 31 et seq.

${ }^{12}$ Calliess, The Making of Transnational Contract Law, Ind. J. Global Legal Stud. 14 (2007) 2, p. $469-483$ (473) with further references.

${ }^{13}$ Zitelmann, Die Möglichkeit eines Weltrechts, Allgemeine österreichische Gerichts-Zeitung 39 (1888) p. 193.

${ }^{14}$ For the CISG see Ferrari, Quo Vadis CISG? : Celebrating the 25th Anniversary of the United Nations Convention on Contracts for the International Sale of Goods 2005.
} 
enforcement of judgments. ${ }^{15}$ Rather, domestic courts control autonomously whether a foreign judgment is in conformity with public policy. At least in Europe, these issues have partly been mitigated due to intensive integration efforts. ${ }^{16}$ On the global scale, however, the problems remain largely unresolved.

In sum, the economic constitution for the world market lacks a functioning commercial law component. The resulting "constitutional uncertainty" on the international level causes additional transaction costs which often make the unassisted market unavailable as a form of organizing cross-border transactions. ${ }^{18}$

Private ordering as the institutional basis of cross-border trade

As a reaction, traders engaged in cross-border commerce have developed a variety of private governance mechanisms as functional equivalents to a state-organized private law system. It is not a question whether trade works without the protection of a state-organized private law system; it is only a question of how and how well it works. Not only in the modern age, but throughout history traders have managed to protect transactions in a way sufficient to allow economic exchange. There are a great number of studies on the ancient Lex Mercatoria or medieval Law Merchant supporting this fact. ${ }^{19}$ More recently, research covered a variety of

${ }^{15}$ For the Hague Convention on Jurisdiction and Foreign Judgments in Civil and Commercial Matters of 2005, which has still not taken effect, cf. to Baumgartner, The proposed Hague Convention on jurisdiction and foreign judgments : trans-atlantic lawmaking for transnational litigation, 2003.

${ }^{16}$ Especially through the Council Regulation 44/2001 on jurisdiction and the recognition and enforcement of judgments in civil and commercial matters (Brussels I - Regulation), OJ 12/1, the Convention of 16 September 1988 on jurisdiction and the enforcement of judgments in civil and commercial matters (Lugano Convention), the Commision Regulation 805/2004 of the European Parliament and of the Council of 21 April 2004 creating a European Enforcement Order for uncontested claims, the Rome Convention on the law applicable to contractual obligations, adopted on 19 June 1980, and the Commission Regulation 593/2008 of the European Parliament and of the Council of 17 June 2008 on the law applicable to contractual obligations (Rome I) coming into effect in December 2009 and the Commission Regulation 1206/2001 on cooperation between the courts of the Member States in the taking of evidence in civil or commercial matters.

${ }^{17}$ Schmidt-Trenz/Schmidtchen, Private international trade in the shadow of the territoriality of law : why does it work?, Southern Econ. J. 58 (1991) p. 329-338 (331).

${ }^{18}$ In this vein already Schmidtchen/Schmidt-Trenz, Private Law, The World Production Possibility Frontier and the Need for an International "Private Law Community": German Theory of Order and Constitutional Economics at Work, 1989, at p. 34: '[...] trades between 'faceless buyers and sellers' [...] hardly work in international trade. They require a developed legal system and protective safeguard which we encounter only in an ideal domestic economy.' Cf. also Rühl, Effizienzprobleme bei grenzüberschreitenden Rechtsstreitigkeiten, German Working Papers in Law and Economics (2008), at p. 6: 'Constitutional uncertainty caused by the plurality of law can prevent rationally acting parties from concluding cross-border transactions and, hence, lead to the failure of these transactions; whereas national transactions would not fail.'

${ }^{19}$ Among the most popular are: Greif, Reputation and coalitions in medieval trade : evidence on the Maghribi traders, J. Econ. Hist. 49 (1989) 4, p. 857; Greif, The organization of long-distance trade : reputation and coalitions in the Geniza documents and Genoa during the eleventh and the twelfth centuries, J. Econ. Hist. 51 (1989) No. 2, p. 459-462; Greif, The fundamental problem of exchange: A research agenda in Historical Institutional Analysis, Europ. Rev. Econ. Hist. 4 (2000) 3, p. 251-284; Greif, Institutions and the path to modern economy: Lessons from medieval trade, 2006; North, Institutions, transaction costs, and the rise of merchant empires, in: Tracy (ed), The Political Economy of Merchant Empires, 1991, p. 22-40; Milgrom et al., The Role of Institutions in the Revival of Trade: The Law Merchant, Private Judges, and the Champagne Fairs, Econ. Politics 2 (1990) 1, p. 1-23; Clay, Trade Without Law: Private-Order Institutions in Mexican California, J.L. Econ. \& Org. 13 (1997) 1, p. $202-231$. 
private governance mechanisms employed in modern cross-border trade. Relational contracts, trade intermediaries and trade clubs, letters of credit, arbitration tribunals and unilateral control through firm structures are just a selection of popular instruments. ${ }^{20}$

Recent empirical data confirms that in international trade the case-load of commercial courts is by far lower than in domestic trade. ${ }^{21}$ As a general rule it can be said that in international trade the relative weight of public governance mechanisms decreases while the importance of private governance mechanisms increases when compared to domestic trade.

\section{Global eCONOMiC CONSTItUTION OUTSIDE the "SHADOW OF LAW" - CAN PRIVATE ORDERING SUPPORT GLOBAL COMPETITIVE MARKET STRUCTURES?}

So how does this shift towards private governance affect the economic constitution of global markets? In the following sections we will discuss two concerns which put into question whether private ordering is able to reproduce the elements of the economic constitution necessary for competitive market structures on the global level. Firstly, the deficiencies of state-organized commercial law influence market structures, namely causing an elevated extent of vertical integration and thus reinforcing the danger of abuse of dominant positions. Secondly, private governance mechanisms are prone to neglect matters of public interest in favour of private interests. Specifically, we will ponder the question whether by choosing arbitration instead of litigation international traders are able to contract around the ban on cartels.

Vertical integration - An inevitable consequence of private ordering

Vertical integration is the competition law issue which is most closely related to the choice of governance mechanisms. As we will show, any sort of private ordering necessarily implies vertical integration. In order to explain this relationship, we will use the theoretical model of transaction costs economics (TCE). ${ }^{22}$

\footnotetext{
${ }^{20}$ See Calliess et al., Transformations of Commercial Law: New Forms of Legal Certainty for Globalized Exchange Processes?, in: Hurrelmann et al. (ed), Transforming the Golden Age Nation State, 2007, p. 83-108; Dietz/Nieswandt, The Emergence of Transnational Cooperation in the Software Industry, in: Gessner (ed), Contractual Certainty in International Trade - Empirical Studies and Theoretical Debates on Institutional Support for Global Economic Exchanges, 2009, p. 87-106; Dietz, Institutionen und Globalisierung - Eine empirische Untersuchung am Beispiel grenzüberschreitender Softwareentwicklungsverträge, 2010, at p. 65 ff; Sosa, CrossBorder Dispute Resolution from the Perspective of Mid-sized Law Firms - The Example of International Commercial Arbitration, in: Gessner (ed), Contractual Certainty in International Trade - Empirical Studies and Theoretical Debates on Institutional Support for Global Economic Exchanges, 2009, p. 107-156; Konradi, The Role of Lex Mercatoria in Supporting Globalised Transactions: An Empirical Insight into the Governance Structure of the Timber Industry, in: Gessner (ed), Contractual Certainty in International Trade - Empirical Studies and Theoretical Debates on Institutional Support for Global Economic Exchanges, 2009, p. 49-86.

${ }^{21}$ Hoffmann, Schiedsgerichte als Gewinner der Globalisierung? - Eine empirische Analyse zur Bedeutung staatlicher und privater Gerichtsbarkeit für den internationalen Handel, SchiedsVZ (2010) p. 96-101, at p. 100; Hoffmann/Maurer, Entstaatlichung der Justiz - Empirische Belege zum Bedeutungsverlust staatlicher Gerichte für internationale Wirtschaftsstreitigkeiten, ZfRSoz 31 (2010) p. 279-302.

${ }^{22}$ For more details on the model cf. to Williamson, Transaction-cost economics : the governance of contractual relations, J. L. \& Econ. 22 (1979) 2, p. 233-261 and Williamson, Transaction Cost Economics, in: Ménard/Shirley (ed), Handbook of New Institutional Economics, 2005, p. 41-65.
} 


\section{Private ordering, vertical integration, and the assumption of efficient market structures: why common theory fails on global markets}

Based on the 'make-or-buy' decision, TCE analyzes the costs which arise when goods or services are transferred from one economic unit to another. 'Make-or-buy' characterizes the extreme points of a continuum of governance mechanisms which can be used to organize a transaction. On the one hand, an economic actor can 'make' a good or service itself, i.e. completely integrate the production and/or distribution process into its own firm structure. On the other hand, it can 'buy' the good or service externally from a third party on the market. What distinguishes 'market' from 'firm' is the way control is exerted. In a firm, no external actors are involved. Rather, there are only internal transactions between different sub-units of the same firm or corporate group, governed by means of hierarchy, i.e. a command-and-control structure based on property rights. On the market, in contrast, there is no such control over the counterparty of a transaction because both parties are completely independent from each other, i.e. 'at arm's length'-trade.

However, actors are not bound to the extremes of market or firm. They may also combine elements of both, forming 'hybrid' governance mechanisms. Graphically, the spectrum of possible modes of governance for transactions can be depicted as a straight line from market to firm with an infinite number of combinations of both mechanisms in between. Any form of private ordering means departing from market governance and moving towards the firm.

Consequently, it also means employing elements of the way a firm exerts control over transactions. Thus, hybrid governance mechanisms always include elements of dependency and subordination as weaker forms of the hierarchy and orders employed in the firm.

In principle, there are three options to stabilize transactions this way. ${ }^{23}$ First, actors can create dependency by enlarging the number of actors involved in a transaction, so a party defecting from its contractual obligations will face sanctions by third parties, e.g. a loss in reputation. Second, actors can bundle multiple transaction issues, so the counterpart will be bound to its obligations in order to gain the profit from all transactions. Third, business relations can be stretched over time, creating long-term dependencies between the actors. Moreover, these instruments can be combined in order to maximize effects. No matter if relational contracts, trade clubs, or reputation networks are analyzed: all of these mechanisms are based on the said instruments creating a certain level of dependency and/or subordination as elements of vertical integration.

Influenced by the ideas of the so called Chicago School, ${ }^{24}$ modern competition policy employs TCE's 'make-or-buy'-model to support its assessment that vertical integration is per se beneficial. ${ }^{25}$ Depending on the factors specificity, uncertainty, and frequency, it is argued that for each transaction a certain governance mechanism in between market and firm is most suitable,

\footnotetext{
${ }^{23}$ This categorization goes back to the model of Yarbrough/Yarbrough, The Contractual Role of Boundaries: Law and Economics Meets International Organization, Europ. J. Int. Relat. 9 (2003) 4, p. 543-590 (551).

${ }^{24}$ For the main ideas of this school cf. to Bork, The antitrust paradox : a policy at war with itself, 1978 and Posner, The Chicago School of Antitrust Analysis, U. Pa. L. Rev. 127 (1979) p. 925-948.

${ }^{25}$ As one example out of many, this becomes obvious in the Commission Regulation 2790/1999 on the application of Article 81(3) of the Treaty to categories of vertical agreements and concerted practices, OJ L 336/21, especially in recital 6 .
} 
i.e. offers the best compromise between the benefits and disadvantages of either extreme. Markets on the one hand offer low costs of organization and ideal incentives for the actors involved, but on the other hand allow no control over the counterpart's behaviour. The firm, in contrast, offers a maximum of control but suffers from high bureaucratic costs and low incentives. It is concluded that any governance mechanism chosen to organize a certain transaction must be the most efficient instrument, for if the compromise between market and firm elements was not ideal, it would eventually be crowded out by the force of competition. As a macroeconomic consequence, it is argued that due to the pressure of competition the benefits gained from this efficient choice of governance mechanisms will eventually be passed on to the consumer.

However, this reasoning is conclusive only under circumstances found within modern nation states. The 'make-or-buy'-model takes for granted an institutional framework which grants free choice between the market and the firm. But this is the case only if there is a system of private law which reliably protects property rights and enforces contracts. As on the free market actors are not able to exert any influence on the counterpart's behaviour, market governance is dependent on an external governance mechanism safeguarding transactions. Such external protection is guaranteed by the private law systems which developed nation states provide for domestic trade, but - as shown above - not for cross-border trade. ${ }^{26}$ Outside the 'shadow of law', actors in cross-border trade are forced to revert to private governance-mechanisms and thus use means of vertical integration. Consequently, the level of vertical integration in cross-border transactions will be higher than in domestic trade, given that all other factors - i.e. the frequency, uncertainty and specificity of transactions - remain unchanged.

What implications does this have on the assessment of vertical integration? Looking at single transactions it is true that vertical integration is indeed efficient. In fact, in situations where there is no system of private law enabling market transactions, private ordering and thus vertical integration is the only way to organize economic exchange. However, this does not support the conclusion that vertical integration is beneficial in general. Rather, from a macro-economical point of view, the elevated level of vertical integration on global markets is quite alarming. Due to the euphoria about the efficiency advantages of vertical integration, its costs and incentive disadvantages vis-à-vis markets are neglected. Control is costly. Hybrid governance mechanisms such as letters of credit or arbitration entail significant additional transaction costs. Trade clubs and trade intermediaries take commissions. Even to the extent that international trade is safeguarded by a transaction-specific mélange of public and private governance mechanisms, ${ }^{27}$ already in the negotiation phase significant transaction costs arise through the involvement of international law firms. Moreover, vertical integration abolishes market incentives and causes friction within the organizational apparatus ('X-Inefficiency').

Due to these disadvantages, O. E. Williamson - one of the leading TCE scholars - called the firm-internal conduct of transactions the organizational form of last resort. He gives clear guidance: "try markets, try hybrids, and have recourse to the firm only when all else fails."28 Vertical integration is economically beneficial only if the specificity, uncertainty and frequency

\footnotetext{
${ }^{26}$ In this vein also Dixit, Lawlessness and Economics: Alternative Modes of Governance, 2004, at p. 3: 'Thus conventional economic theory does not underestimate the importance of law; rather, the problem is that it takes the existence of a well-functioning institution of state law for granted.'

${ }^{27}$ See Calliess et al., Transformations of Commercial Law: New Forms of Legal Certainty for Globalized Exchange Processes?, in: Hurrelmann et al. (ed), Transforming the Golden Age Nation State, 2007, p. 83-108.

${ }^{28}$ Williamson, The economics of governance, Amer. Econ. Rev. 95 (2005) 2, p. 1-18 (12).
} 
of transactions justify the high level of time and effort used. Otherwise market governance is the more attractive organizational form, as it allows a leaner internal administration and offers optimal incentive structures through competition.

Not only in theory, but also in economic practice it can be observed that economic actors recognize and utilize the advantages of a low level of vertical integration if circumstances allow them to do so. In order to save administrative costs and to gain flexibility, corporations tend to decouple activities outside of their core competencies from the hierarchy of the firm and to transfer them to other companies by virtue of outsourcing and off-shoring. However, economic studies demonstrate that corporations tend to outsource only into those countries in which legal institutions provide for an efficacious enforcement of contracts. ${ }^{29}$

To sum up, vertical integration does enable global economic exchange - but only at high costs. Via the final price for any good or service provided across borders, the consumer pays the profit margin of providers of private governance mechanisms. Against this background, vertical integration is not per se beneficial, but may have been chosen as an inferior type of governance mechanism only because market governance was unavailable due to the deficits of the international private law system. The tailor-made governance solutions of transnational commerce lack the economies of scale that a state-organized private law regime offers as safeguarding mechanism for the multitude of relatively unspecific transactions. ${ }^{30}$ Thus, for the sake of a conclusive assessment of vertical integration, it is not enough to lean back and be comfortable with the lax treatment in competition law.

\section{No comprehensive remedy for vertically concentrated market structures to be expected}

A solution to this problem seems hard to reach in practice, though. Adopting stricter competition rules vis-à-vis vertical integration would be counterproductive: due to the deficits of private law on the international level private ordering, and thus vertical integration, is the only mechanism enabling cross-border trade. Theoretically, only improvements of international commercial law as part of a world economic constitution - i.e. the protection of property rights and the enforcement of contracts across national borders as those parts of the economic constitution necessary for the emergence of market economies - would tackle the root of the problem. ${ }^{31}$ However, so far all the dreams of a world private law have been disappointed, though - provided

\footnotetext{
${ }^{29}$ Grossman/Helpman, Outsourcing in a Global Economy, Rev. Econ. Stud. 72 (2005) 1, p. 135-159; Nunn, Relationship-Specificity, Incomplete Contracts, and the Pattern of Trade, Q. J. Econ. 122 (2007) 2, p. 569-600.

${ }^{30}$ Dietz, Institutionen und Globalisierung - Eine empirische Untersuchung am Beispiel grenzüberschreitender Softwareentwicklungsverträge, 2010, Chap. 2, point 4.2.

${ }^{31}$ Cf. to Behrens, Weltwirtschaftsverfassung, JNPÖ 19 (2000) p. 5-27; For background information on the model of an economic constitution cf. to Kerber/Vanberg, Constitutional Aspects of Party Autonomy and Its Limits - The Perspective of Constitutional Economics, in: Grundmann et al. (ed), Party autonomy and the role of information in the internal market, 2001, p. 49-79; Behrens, Die Bedeutung des Kollisionsrechts für die "Globalisierung" der Wirtschaft, in: Basedow et al. (ed), Aufbruch nach Europa: 75 Jahre Max-Planck-Institut für Privatrecht, $2001, \mathrm{p}$. 381-398 (384 et seq.).
} 
the political will - at least partial improvements would be possible. ${ }^{32}$ Success stories like the European Union show that unifying legal systems across national borders can work in practice. On the global level, however, no similar development is in sight. Against the background of diverse national interests and judicial conflicts, at least in the closer future no comprehensive approach has any realistic chance to succeed.

International arbitration - An instrument able to support competitive structures on the world market?

Even if national systems of private law cannot sufficiently protect international transactions, does not international commercial arbitration offer a viable solution to conduct trade between anonymous parties across borders and thus allow cross-border market governance?

\section{Arbitration as an instrument partially enabling cross-border market trade}

Frequently relied on in international trade, arbitration indeed serves the same function as statebased court systems as far as facilitating trade is concerned. Contractually equipped with jurisdictional powers for a specific transaction, arbitral tribunals serve as independent third parties resolving the prisoner's dilemma between anonymous actors. Most importantly, the enforcement of the tribunals' decisions does not necessarily have to rely on dependency and subordination, as is usually inherent to private ordering. Rather, decisions are enforceable via the nation states' private law systems: Having ratified the so called $1958 \mathrm{New}$ York Convention, most countries enforce decisions of arbitral tribunals via the apparatus of their private law systems with only very limited options of de novo review of the decision.

It must be kept in mind, however, that due to several shortcomings arbitration does not offer the same universal kind of protection as guaranteed by state-based private law systems. Whereas the latter are accessible for any sort of claims, international arbitration favours economically powerful players and high-value transactions. ${ }^{33}$ This mainly results from the relatively high costs of arbitration procedures. ${ }^{34}$ Paying extremely high fees for arbitrators and councils alike - mostly lawyers from international law firms with hourly wages well beyond $350 €-$ is reasonable only, if justified by the sum at stake. Empirical research shows that a small claim procedure in front of state courts costs only a fraction of what the same procedure in arbitration. ${ }^{35}$ While access to justice in front of public courts is granted by constitutional law, e.g. Article 6 ECHR, and backed by legal aid for destitute parties, arbitral tribunals will deny opening procedures if a party is not able to make an advance payment for the expected costs.

Further, two additional structural deficits of arbitration limit its institutional reach. First, arbitral tribunals often do not publish their awards. Thus, arbitration does not allow for the production of legal certainty for third parties which is a by-product of judicial precedent. Second, arbitral

\footnotetext{
${ }^{32}$ A plethora of suggestions for improving the state protection of private law can be found in Calliess/Hoffmann, Effektive Justizdienstleistungen für den globalen Handel, ZRP (2009) p. 1-4.

${ }^{33}$ For an extensive analysis of the role of international arbitration for small and medium-sized enterprises cf. to Parise-Kuhnle, Transaktionssicherheit im Außenhandel durch prozessualen Rechtsschutz - eine Untersuchung aus der Perspektive kleiner und mittelständischer Unternehmen, CRC 597 „Transformations of the State“ Working Paper Series, forthcoming.

${ }^{34}$ For the cost structure of arbitration cf. to Schütze, Schiedsgericht und Schiedsverfahren, 2007, at p. 12; Henn, Schiedsverfahrensrecht - Handbuch für die Praxis, 2000, at p. 194 et seq.; Hoffmann, Nationale Ziviljustiz und internationaler Handelsverkehr - ein Vorschlag zur Einrichtung von Kammern für internationale Handelssachen, Dissertation Bremen, 2010, at p. 52 et seq.

${ }^{35}$ Lachmann, Handbuch für die Schiedsgerichtspraxis, 2008, marginal numbers 4682 et seq.
} 
wards are final and binding, i.e. there are no stages of appeal involved in which decisions are reviewed in substance for their overall consistency and coherency. This lack of control makes arbitration prone to biased and unpredictable decisions, calling into question the fairness of the proceedings. Without any objective control according to common legal standards, arbitrators might be tempted to render the decision most favourable to economically powerful parties because as repeat players they will most probably be able to channel future arbitration business to them. For experienced lawyers it is easy to justify any outcome of the proceedings in a way that is not contestable by the very limited means of control of national courts over arbitral awards. Since it takes a violation of domestic public policy in order to successfully contest an arbitral award in front of a state court, such proceedings are rarely successful. Whereas economically powerful players have the capacity to cope with the resulting unpredictability, the risks might be too high for small and medium-sized enterprises facing bankruptcy in case of unfavourable awards. ${ }^{36}$

To sum up, arbitration is neither accessible to the broad public, nor does it grant a level of justice comparable to a state-organized system of private law. Nevertheless, arbitration supported by public enforcement via the 1958 New York Convention is able to lay the foundation for at arm's length market transactions at least for economically powerful, repeat players. In this limited respect, international arbitration does indeed enable market transactions between independent and anonymous trade partners on the global level.

\section{Private vs. public interest: Is arbitration able and willing to protect the antitrust law?}

If arbitration enables cross-border trade between anonymous parties and thus allows for competitive international market structures, then why should it raise any issues as far as competition law is concerned? In order to answer this question one needs to look at the different interests involved in the governance of transactions.

Primarily, private governance mechanisms serve the interests of the transacting parties. They are functional equivalents to state-organized private law systems as far as the trade-facilitative function is concerned. Arbitrators, for instance, offer services as professional trade facilitators: they are engaged and paid for by the transacting parties and render their award in order to enforce contractual obligations. In other words, they are primarily bound to the private interests of the transacting parties as their customers.

The protection of competition, however, is a goal of public interest. Competition law forms part of regulatory law limiting individual freedom in order to achieve better economic results for the public. Thus, at least from an ex-ante point of view it usually runs counter to the interests of private parties involved in a certain transaction. As public institutions, state courts have to consider both the facilitative and the regulatory aspects of private law. While enforcing

\footnotetext{
${ }^{36}$ For further details on the relation between the economic power of the parties and their access to arbitration cf. to Knapp, Taking Contracts Private: The Quiet Revolution in Contract Law, Fordham L. Rev. 71 (2002-2003) p. 761798 (781); Budnitz, The High Cost of Mandatory Consumer Arbitration, Law \& Contemp. Probs. 67 (2004) p. 133, 161; Drahozal, Arbitration Costs and Contingent Fee Contracts, SSRN Working Paper (2005) .
} 
commercial contracts and protecting property rights, at the same time they have to exercise public control functions by limiting the private autonomy of commercial actors with regard to public interests and public good.

It is highly doubtful, however, whether and to what extent arbitral tribunals as private institutions have the obligation, capacity, and willingness to take into account matters of public policy. As in principle international arbitral tribunals are not bound to apply specific national regulatory rules, it comes natural to assume that interests of the public are neglected in favour of the private interests of the transaction parties. Already the German Reichsgericht noted that "only an unconditional submission under a specific lawmaking authority [...] guarantees that the contractual relationship will be regulated, if necessary, against the selfish will of the economically stronger partner or of both partners, with regard to those public policy concerns that are based on general principles of law.",37

Some proponents of the New Law Merchant, however, do not agree with these concerns. They argue that transnational commercial law not only encompasses substantive legal norms in the interest of the contracting parties, but also creates its very own transnational public policy norms. Specifically, Gunther Teubner has proposed the idea that private governance regimes are bound to 'auto-constitutionalize', i.e. to develop a body of higher-ranking norms functionally equivalent to national constitutional law. ${ }^{38}$ Therefore, the argument goes on, the transnationalization of law is not per se problematic: Law beyond the state is not necessarily inferior to state-made law when it comes to accommodating public policy concerns. From this perspective, transnational law may even be depicted as being able to overcome the public/private distinction as such, by way of establishing more inclusive processes of regulation that involve both state and non-state, civil society actors. ${ }^{39}$

A thorough analysis of international arbitral awards reveals that neither the fears nor the hopes voiced with regard to public policy in international arbitration are entirely justified. This follows from the precarious status of the arbitration regime itself. While international arbitration enjoys a high degree of autonomy from domestic legal systems, at the same time it is not wholly independent from the state. Arbitral tribunals do not form part of any domestic jurisdiction but are still heavily influenced by and dependent on domestic procedural law and state courts. This tension goes back to the hybrid character of international arbitration ${ }^{40}$ combining privately organized tribunals and proceedings with public means of enforcement, as reflected by the 1958 New York Convention. According to this almost universally ratified convention, on the one hand, the autonomy of the private character of the proceedings is respected as all State Parties to the Convention must enforce awards rendered by international arbitral tribunals on their territory without de novo review as to their substance. ${ }^{41}$ On the other hand, a certain protection of public interests is granted as in a strictly limited number of situations recognition and enforcement may be refused, especially if such enforcement were contrary to the public policy of the country

\footnotetext{
${ }^{37}$ Reichsgericht, Juristische Wochenschrift (1936), p. 2058 (2059) (our translation).

${ }^{38}$ Teubner, Global Private Regimes: Neo-spontaneous Law and Dual Constitution of Autonomous Sectors in World Society, in: Teubner/Ladeur (ed), Globalization and Public Governance, 2004, p. 71 ; Fischer-Lescano/Teubner, Regime-Collisions: The Vain Search for Legal Unity in the Fragmentation of Global Law, Michigan Journal of International Law 25 (2004) 4, p. 999.

${ }^{39}$ See Teubner, Contracting Worlds: The Many Autonomies of Private Law, Social and Legal Studies 9 (2000) p. 399-417.

${ }^{40}$ See generally Schlosser, Das Recht der internationalen privaten Schiedsgerichtsbarkeit, 1989.

${ }^{41}$ New York Convention on the Recognition and Enforcement of Foreign Arbitral Awards, June 10, 1958, 330

U.N.T.S. 38, at Art. III.
} 
where enforcement is sought. ${ }^{42}$ For the same reason, an arbitral award may be set aside by domestic courts under Art. 34 para 2(b)(ii) of the UNCITRAL Model Law on International Commercial Arbitration (UNCITRAL Model Law), on which the procedural law concerning arbitration is based in most states. Thus, the New York Convention defines both the independence and the limits of international arbitration vis-à-vis domestic regulation. While based on the will of the parties and the discretion of the arbitrators the tribunal is free to apply the law deemed appropriate to satisfy the private interests of the conflict parties, a certain protection of public interest is granted by the necessity to render a valid and enforceable award. Also the arbitration rules of the International Chamber of Commerce (ICC) in Paris, the leading provider of international commercial arbitration services worldwide, reflect this tension. According to Art. 17 para 1 of the ICC Arbitration Rules, "[t]he parties shall be free to agree upon the rules of law to be applied by the Arbitral Tribunal to the merits of the dispute. In the absence of any such agreement, the Arbitral Tribunal shall apply the rules of law which it determines to be appropriate." Article 35 of the Rules, in contrast, provides that "[i]n all matters not expressly provided for in these Rules, the Court and the Arbitral Tribunal shall . . make every effort to make sure that the Award is enforceable at law." In addition, Art. 6 of the Internal Rules of the ICC Court of Arbitration provides that all ICC arbitral awards are scrutinized by the ICC's central administrative body with regard to requirements of the "law of the place of arbitration."

The tension between autonomy and public oversight in arbitration is reflected on the level of the applicable substantive law, specifically with regard to the application of mandatory rules of law. In domestic legal systems, mandatory rules of law are norms which cannot be derogated from by agreement of the parties - and thus limit party autonomy. This limitation is based on the assumption that certain 'fundamental' norms must not be left at the parties' disposal. It is well established that state courts, when they enforce commercial contracts and protect property rights, at the same time exercise public control functions with regard to (1) public interests or public good such as a workable competition or a stable currency, (2) the effects of contracts on third parties, e.g. on creditors outside the contractual relationship, and (3) the protection of weaker parties within the contract itself, such as the protection of consumers or employees against the unilateral exercise of private autonomy by economically dominant actors.

Even in cross-border disputes, domestic courts apply certain mandatory norms, regardless of the law otherwise applicable, as 'overriding mandatory provisions' (e.g. Art. 9 Rome I Regulation) or with reference to the 'public policy of the forum' (e.g. Art. 21 Rome I Regulation). The doctrinal reconstruction of such mandatory norms in conflict-of-laws rules widely differs among jurisdictions and relies on very diverse doctrinal concepts. ${ }^{43}$ Usually, the reach of 'overriding' mandatory provisions, i.e. those mandatory provisions which are applicable to cross-border disputes, is considered as more limited than that of 'ordinary' mandatory, i.e. purely domestic norms: Only those mandatory norms which protect 'essential regulatory interests' of the state

\footnotetext{
${ }^{42}$ Id. At Art. V para. 2 (b).

${ }^{43}$ For the status of mandatory rules in conflict of laws see especially Guedj, The Theory of the Lois de Police, A Functional Trend in Continental Private International Law - A Comparative Analysis with Modern American Theories, American Journal of Comparative Law 39 (1991) 4, p. 661-697 as well as Hartley, Mandatory Rules in International Contracts: The Common Law Approach, Recueil des Cours 266 (1997) p. 337-426.
} 
concerned are applied to cross-border situations. ${ }^{44}$ Furthermore, there is disagreement as to the question whether domestic courts should only apply the overriding mandatory provisions of the forum state or also those of third states. Nonetheless, the concept of internationally mandatory norms protecting public policy is entrenched in every domestic system of conflict of laws. Things become more complicated when it comes to arbitration, though. As arbitral tribunals in international cases do not serve as guardians of any national public policy, they are in principle not obliged to apply the mandatory rules of any country's jurisdiction. Rather, as recognized in the 1958 New York Convention, arbitration is based on contractual choice-of-law and choice-offorum clauses. Consequently, the parties of a contract are free to choose the procedural and substantive rules applicable to any potentially arising conflict and thus to 'opt out of regulation, 45 .

Classical conflict-of-laws methods for dealing with this problem have proven rather unsatisfactory in arbitration as they are deeply rooted in national preconceptions of public policy and the fact that domestic courts are bound by a specific national constitutional order. International arbitral tribunals, in turn, do not have ties to any specific legal system. Though physically seated within a national jurisdiction, it is assumed by most scholars and practitioners that arbitral tribunals do not have a forum state. Rather, international arbitral tribunals operate delocalized and disconnected from domestic laws and policies. This results in the paradoxical situation that for an arbitrator, "there is no foreign law" 46 while at the same time, "every law is foreign law", 47

\section{Difficulties in the emergence of transnational competition law}

Consequently, there is no clear-cut solution as to the application of mandatory law in international arbitration. Still, it is commonly accepted that also in arbitration, matters of public policy have to be recognized and protected at least to a certain degree. The question is, however, which rules have to be applied in order to grant that protection.

For international arbitrators confronted with this question there is not much legal guidance. The necessity to render an enforceable award forces the arbitrator to take into account the mandatory law of nation states potentially involved in the enforcement of the award, at least as far as breaches of those rules also lead to a violation of national public policy. The problem is, however, that usually it is not possible to predict in which country an award is going to be enforced. Acknowledging this difficulty, there have been attempts to develop a system of 'transnational public policy' based on the ground-breaking work of Pierre Lalive ${ }^{48}$ in order to

\footnotetext{
${ }^{44}$ Renner in Calliess (ed.), The Rome Regulations. Commentary on the European Rules of the Conflict of Laws, art. 9, paras 13-20.

${ }^{45}$ O'Hara, Opting Out of Regulation: A Public Choice Analysis of Contractual Choice of Law, Vanderbilt Law Review 53 (2000) p. 1551-1604.

${ }^{46}$ Derains, Public Policy and the Law Applicable to the Dispute in International Arbitration, in: Sanders (ed), Comparative Arbitration Practice and Public Policy in Arbitration, 1987, p. 227-256 at p. 232.

${ }^{47}$ Voser, Mandatory Rules of Law as a Limitation on the Law Applicable in International Commercial Arbitration, American Review of International Arbitration 7 (1996) 3/4, p. 319 (330).

${ }^{48}$ See Lalive, Ordre public transnational (ou réellement international) et arbitrage internationale, Revue de l'arbitrage (1986) p. 327-373; English language version published as Lalive, Transnational (or Truly International) Public Policy in International Arbitration, in: Sanders (ed), Comparative Arbitration Practice and Public Policy in Arbitration, ICCA Congress Series No. 3, 1987, p. 257-318, at p. 286. Similarly, the recommendations of the International Law Association Committee on International Commercial Arbitration, Report on Public Policy as a
} 
carve out a concept of mandatory norms irrespective of the particularities of national law. However, apart from undisputed core elements like the recognition of the jus cogens of international law, anti-corruption rules, the principles of universal justice, and a minimum standard of human rights, there is no common understanding of which norms form part of transnational or truly international public policy. In absence of a 'world-constitution' the status of normative hierarchies in transnational law remains largely unresolved.

Notwithstanding these difficulties, some very important domestic courts have expressed high expectations as far as specifically the application of competition law by arbitral tribunals is concerned. In its famous Mitsubishi decision ${ }^{49}$ in 1985 the US Supreme Court held that a contractual dispute between a Puerto Rican and a Japanese party was arbitrable although the contract potentially violated the US Sherman Act and thus American public policy in antitrust law. The Supreme Court argued that an arbitration procedure would not violate public policy since the Japanese arbitral tribunal would apply the Sherman Act just the same as an American court would do. Complementary to the Supreme Court's decision, the ECJ ruled in the Eco Swiss case $^{50}$ that all courts in EU Member States are obliged to annul arbitral awards that are contrary to Art. 81 EC Treaty (now Art. 101 Treaty on the Functioning of the European Union; TFEU). The reasoning was twofold: the ECJ argued that on the one hand antitrust law formed an integral part of European public policy, allowing annulment according to Art. 34 para 2(b)(ii) UNCITRAL Model Law, and on the other hand a disregard of antitrust law justified refusing the recognition and/or enforcement of arbitral awards under Art. V para 2(b) of the New York Convention.

The message to arbitral tribunals involved in both decisions is rather clear: domestic courts consider competition law to form an integral part of public policy which has to be respected by international arbitration, and any disregard thereof will result in annulment of the award and refusal of its recognition and enforcement. However, even if an arbitrator willing to render an enforceable award knows only that he has to take into account competition law, the courts' decisions do not give him any further guidance as to how he has to apply competition law, namely which rules he has to apply according to what rules of conflict.

Against the background of this conflict, it must be asked how international arbitral tribunals cope with the application of competition law in practice. In order to clarify this matter, we have conducted an empirical case-by-case analysis of international arbitral awards. ${ }^{51}$ This analysis reveals that despite all doctrinal difficulties arbitral tribunals are willing and able to apply competition law, specifically the ban on cartels as codified in Art. 101 TFEU. In the last 15 years there have been numerous cases decided by arbitral tribunals instituted by the Court of Arbitration of the International Chamber of Commerce (ICC) dealing with matters of

Bar to Enforcement of International Arbitral Awards (2002), Recommendation 2(b) rely on "the existence or otherwise of a consensus within the international community as regards the principle under consideration."

${ }^{49}$ See Mitsubishi Motors v. Soler Chrysler-Plymouth, 473 U.S. 614 (1985).

${ }^{50}$ See Case C-126/97, Eco Swiss China Time Ltd v. Benetton International NV (1999).

${ }^{51}$ This analysis was performed by Moritz Renner in preparation of his doctoral thesis. The full results of the study are published in Renner, Zwingendes transnationales Recht - Zur Struktur der Wirtschaftsverfassung jenseits des Staates, 2011, at p. 92 et seq. 
competition law. ${ }^{52}$ The analysis of those cases shows that arbitral tribunals do apply competition law provisions in principle. The dilemma of which rules to apply is solved in a rather pragmatic manner. Without resorting to any common methodology, arbitrators employ rules from different normative levels in order to justify the application of competition law.

This inconsistency of methodology and the lack of judicial review by an appellate body, however, sometimes lead to troubling inconsistencies of arbitral case-law. This can be exemplified by two contradictory decisions in rather similar cases: whereas one tribunal held that, following the Mitsubishi case and the general consideration that arbitrators "should always be concerned about the efficacy of their awards", Art. 101 TFEU had to be applied to a contract even though the parties had chosen New York State law as applicable law, ${ }^{53}$ another tribunal flatly ruled that antitrust disputes were not arbitrable under New York State law - and therefore left antitrust law unapplied. ${ }^{54}$

Most awards which are concerned with antitrust norms, however, simply take their applicability for granted if those rules form part of the law applicable to the contract as a whole. ${ }^{55}$ If, for example, the parties have agreed on Belgian law as applicable to their contract, arbitrators would not engage in any further methodological reasoning but simply apply European antitrust law as part of the mandatory law common to all EU Member States. Consequently, as this focus on the chosen law regime invites parties to escape from strict regulation by choosing the most lenient law, arbitral tribunals incidentally use more sophisticated conflict-of-law arguments in order to justify an application of European antitrust law even if the parties have chosen the law of a third state. However, while in such cases domestic courts would rely on the so called 'loi de police' or the 'governmental interest analysis' method, arbitral tribunals prefer the 'law as a fact'doctrine, ${ }^{56}$ which allows them to take into account merely the factual effects of mandatory norms beyond the chosen law without, however, granting them force of law. For example, an arbitral tribunal might refer to force majeure provisions under the chosen law in order to rule that a contract infringing European anti-trust law is unenforceable.

Problems intensify in those arbitration proceedings which allow the decision of conflict by amiable composition, i.e. not according to specific rules of law but according to general considerations of equity and the customs of international trade. As by choosing this type of proceedings the parties have expressed the clear will to exempt their contractual relation from the rule of law altogether, arbitral tribunals might argue that consequently the contractual relation should not be subject to any national regulatory law, neither. In the line of this argument, the only regulatory limit to the parties' autonomy is transnational public policy as part of the lex mercatoria. In this vein, an arbitral tribunal sitting in Switzerland ruled that European antitrust law did not form part of transnational public policy. ${ }^{57}$ Considering the divergent approaches to

\footnotetext{
${ }^{52}$ See, e.g. ICC cases no. 6503, (1990), 122 J. DROIT INT’L (CLUNET) 1022-1031 (1995); 7146 (1992), Y.B. COM. ARB. XXVI 119-129 (2001); 7181 (1992), Y.B. COM. ARB. XXI 99-112 (1996); 7539 (1995), J. DROIT INT'L (CLUNET) 1030-1037 (1996); 7893 (1994), Y.B. COM. ARB. XXVII 139-152 (2002); 8423 (1994), J. DROIT INT'L (CLUNET) 1079-1082 (2002); 8626 (1996), J. DROIT INT'L (CLUNET) 1073-1079 (1999); 10988 (2003), J. DROIT INT'L (CLUNET) 1408-1417 (2006).

${ }^{53}$ See ICC Case No. 8626 (1996), J. DROIT INT'L (CLUNET) 1073-1079 (1999).

${ }^{54}$ See ICC Case No. 7893 (1994), Y.B. COM. ARB. XXVII 139-152 (2002).

${ }^{55}$ See ICC Cases No. 7146 (1992), Y.B. COM. ARB. XXVI 119-129 (2001); 7181 (1992), Y.B. COM. ARB. XXI 99-112 (1996); 7539 (1995), J. DROIT INT'L (CLUNET) 1030-1037 (1996) ; 8423 (1994), J. DROIT INT'L (CLUNET) 1079-1082 (2002); 10988 (2003), J. DROIT INT'L (CLUNET) 1408-1417 (2006).

${ }^{56}$ See Ehrenzweig, Local and Moral Data in the Conflict of Laws, Buffalo Law Review 16 (1966) p. 55; Kay, Conflict of Laws: Foreign Law as Datum, California Law Review 53 (1965) p. 47.

${ }^{57}$ See ICC case no. 6503 (1990), J. DROIT INT'L (CLUNET) 1022-1031 (1995).
} 
antitrust law in different jurisdictions, this reasoning is convincing. How to design competition law is a highly disputable political question traditionally decided within the democratic decisionmaking processes of the constitutional nation-states. For this reason it is to be doubted that beyond hard-core cases of anti-competitive behaviour there will ever be universal rules giving guidance to arbitrators in the transnational context. ${ }^{58}$

\section{CONCLUSION}

To answer the leading question of this article: The world market can reproduce its own prerequisites - but to a limited extent only.

First, it cannot be denied that private ordering is able to substitute for state-organized commercial law. However, on the one hand, the tailor-made governance mechanism employed in cross-border trade lack the economies of scale that a state-organized private law regime offers as safeguarding mechanism for the multitude of relatively unspecific market transactions. On the other hand, as private ordering builds on dependency and command-and-control structures and thus necessarily implies vertical integration, international market structures suffer from a higher level of economic concentration and are more prone to the abuse of dominant market positions. Consequently, private ordering as opposed to state-organized commercial law allows crossborder trade at high costs and little market incentives only.

Second, as far as the competition law component of the world economic constitution is concerned, the example of international arbitration shows that private governance mechanisms are able to reproduce constitutional elements to a certain extent, but are still far from a comprehensive solution. As shown above, the application of competition law by arbitral tribunals suffers from several inconsistencies. Also the development of a comprehensive 'transnational competition law' seems unlikely due to the different national approaches to antitrust regulation. However, this should not block the view from the positive results of our analysis of ICC awards. Even if the tribunals' reasoning may be inconsistent or sometimes not convincing: at least ICC tribunals - in the vast majority of cases - are able and willing to apply competition law as soon as they decide according to rules of law. It has become clear that arbitration cannot be regarded as a governance mechanism generally allowing parties to 'opt out of regulation'. Already at the current point of time, parties agreeing on an arbitration clause have to expect that a tribunal resolving any potential conflict in the contractual relation will consider the protection of competition as a goal of public interest, even if this runs counter to the ex-ante private interests of the parties. Partly this is a result of the fact that from an ex-post perspective, i.e. after a conflict has arisen, one party often has an interest in voiding the contract and, therefore, refers to the ban on cartels as an issue of public policy.

Within the European Union, the application of competition law is guaranteed by the jurisdiction of the ECJ. Since according to the decision in the Eco Swiss case awards contrary to EU

\footnotetext{
${ }^{58}$ Cf. to Kahn, Les principes généraux du droit devant les arbitres du commerce international, Journal du droit international (1989) p. 305-327 (317); Idot, Les conflits de lois en droit de la concurrence, Journal du droit international (1995) p. 321-341 (328 et seq.); for perspectives cf. to Basedow, Weltkartellrecht : Ausgangslage und Ziele, Methoden und Grenzen der internationalen Vereinheitlichung des Rechts der Wettbewerbsbeschränkungen, 1998 , at p. 94 et seq.
} 
competition law will be annulled by any public court in the Member States of the EU, any arbitral tribunal sensitive to the criteria laid down in Art. 35 of the ICC rules will apply competition law. Since it is one of the main goals of arbitration to render enforceable awards useful to the parties, any award potentially enforceable within the EU will consider competition law. As a large part of world trade is at least indirectly connected to the EU and thus might involve the enforcement of an award in Europe, the ECJ's legislation has great impact. If other economically powerful jurisdictions were to implement similar rules, the universal application of competition law by arbitral tribunals could be put on a more stable foundation.

Also changes to the procedural rules of international arbitration itself could further enhance the uniform application of competition law. In the long run it seems inevitable to push for a more thorough publication of awards in order to both allow a broader discussion of arbitral awards and enable arbitral tribunals to carve out more consistent decision-making criteria on a case-by-case basis.

The upshot for the development of a more efficient and fair world economic constitution is that public players will have to actively support the world market in reproducing its institutional prerequisites. While private ordering is able to allow a respectable level of cross-border commerce and enforce antitrust law to a certain extent, both the commercial law and the competition law element of the current world economic constitution remain under-developed in contrast to its domestic role models. In the long run, only further cooperation of national private law systems across borders will help lowering the level of vertical integration in international trade and thus allow fair market structures. Also, as far as the application of antitrust rules by arbitral tribunals is concerned, nation states will have to keep up the pressure on international arbitration organisations to apply and enforce competition law. 